\title{
Analysis of the efficiency of a solid fuel boiler depending on the choice of combusted fuel
}

\author{
Grzegorz Pełka ${ }^{1, *}$, Wojciech Luboń ${ }^{1}$, and Przemysław Pachytel $^{1}$ \\ ${ }^{1}$ AGH University of Science and Technology, Faculty of Geology, Geophysics and Environmental \\ Protection, Department of Fossil Fuels, Mickiewicz Ave. 30, 30-059 Cracow, Poland
}

\begin{abstract}
In the municipal and residential sector in Poland, as many as $50 \%$ of households are heated by solid fuel boilers. Most often these are, unfortunately, inefficient boilers, fired with low-quality coal. This study characterizes the market of boilers for solid fuels in Poland, and also presents the main apportionment of these devices, due to the different criteria that characterize them. The current legal changes in the scope of energy and emission requirements for solid fuel boilers are also discussed. The main purpose of this work is to analyze the real efficiency of the solid fuel over-fired boiler used, depending on the fuel burned in it. The process of burning selected fuels (seasoned wood, coal and pea coal) in the boiler was preceded by tests of these fuels to determine their energy parameters, such as moisture, ash content, the share of volatile matter and calorific value. In the next step, the energy efficiency obtained by the tested solid fuel boiler during the combustion of selected solid fuels was compared. The highest efficiency was achieved during the combustion of pea coal, and the lowest was achieved during the combustion of wood. In any case, the nominal efficiency value was achieved. Solutions that could improve the quality of the combustion process in this type of boiler were proposed.
\end{abstract}

\section{Introduction}

Single-family housing is a dynamically developing sector of housing in Poland. Choosing fuel for heating is one of the most important decisions to take. The owner of the house must take into account the price of the energy, i.e. the costs of heating, the place for storing the fuel, the comfort of servicing the heating device and, what is recently very important and subjected to discussion, the impact of the energy source on the natural environment. Recently, a major problem is the phenomenon of low stack emissions, i.e. products of burning solid, liquid and gaseous fuels into the atmosphere from emission sources (emitters) located at an altitude of no more than $40 \mathrm{~m}$ [1]. This leads to the introduction of such technical solutions, supported by legal requirements, which will significantly reduce the emissions from the municipal and housing sector.

At present, households still have outdated heating systems, the main element of which are low-efficiency, manual feed, solid fuel boilers. They were, however, the cheapest

\footnotetext{
* Corresponding author: gpelka@geol.agh.edu.pl
} 
solution available on the market, therefore, despite the enormity of defects, they still constitute the largest percentage in distributed municipal and rural heating [2].

\section{Purpose of research}

The main purpose of the research is to determine the real efficiency of the manual feeding solid fuel boiler, depending on the burned fuel. This research is to show how efficient is the process of converting chemical energy contained in the fuel into heat transferred carrier which is heating the object. The tests will allow the determination of the obtained capacity and real efficiency achieved in a solid fuel boiler fired by seasoned wood and various types of hard coal.

\section{Current status in the scope of using solid fuel boilers in Poland}

Poland is the European leader in the use of coal for heating purposes in residential buildings [3]. According to the Central Statistical Office, in 2015, solid fuels were used by $49.2 \%$ of households. The most commonly used fuel in households is coal - approx. $32 \%$, and firewood accounted for over $13 \%$ of total consumption [4]. Most of the boilers currently used do not fulfill any energetic and emission criteria, the result of a lack of legal regulations in this area until recently.

Another key aspect is the problem of energy poverty, caused by the poor financial situation of families, especially in small towns and regions affected by the problem of unemployment. Energy poverty is a problem with maintaining thermal comfort in the building, caused by a lack of material means to pay for heating bills or to modernize the existing ineffective heating system [5]. In Poland in 2015, this problem affected approximately $5 \%$ of households [6].

The growing social expectations regarding the reduction of low emission and increased energy efficiency of heating appliances using solid fuels, have resulted in the introduction of ever more restrictive European standards regarding these problems. For this reason, in the near future, boilers introduced on the Polish market will have to achieve the ecodesign requirements for solid fuel boilers.

\section{Description of the test stand and methodology}

The research was carried out in the Center for Sustainable Development and Energy Conservation WGGiOŚ, AGH in Miękinia.

In the Centre there is equipment that enables accurate and real results in the field of analysis of energy parameters of selected solid fuels to be obtained. To determine the moisture of fuels, a specialist Radwag MA50.R moisture analyzer was used. To determine the volatile matter and ash content in the analyzed fuel samples, Nabertherm L9 muffle furnace was used. In order to determine the calorific value, the KL-11 "Mikado" calorimeter was used.

The moisture analysis was carried out in accordance with the moisture analyzer manufacturer's instructions. The results were moisture content in the tested fuel.

The volatile matter in the fuel refers to the dry mass of the fuel which becomes volatile during the heating process at high temperature without air access. The determination of volatile matter was carried out in accordance with the Polish standard PN-81/G-04516 Solid fuels. Determination of volatile matter [7]. 
To determine ash content in the tested fuels, the guidelines included in Polish standard PN-80/G-04512 - Solid fuels were used [8]. Determination of ash content by slow incineration.

Higher calorific value for tested fuels was determined. For this purpose, the KL-11 Mikado calorimeter was used. Based on the higher calorific value, lower calorific value was calculated according to the equation 1 .

$$
Q_{\mathrm{i}}=Q_{\mathrm{s}}-2442 *\left(W_{\mathrm{w}}+8.94 * \mathrm{H}_{\mathrm{daf}} *\left(1-W_{\mathrm{w}}-A\right)\right)(\mathrm{kJ} / \mathrm{kg})
$$

Qi- Lower calorific value $(\mathrm{kJ} / \mathrm{kg})$,

Qs - Higher calorific value $(\mathrm{kJ} / \mathrm{kg})$,

$\mathrm{H}_{\text {daf }}$ - share of hydrogen in the fuel in the dry ash free state (-),

2442 - latent heat of evaporation $(\mathrm{kJ} / \mathrm{kg})$,

8.94 - hydrogen conversion factor for the amount of water produced.

The combustion process was carried out in an over fired solid fuel boiler with a nominal heat output of $12 \mathrm{~kW}$, produced in 2005. This type of boiler is very common in Poland. The device fulfills the 1 class requirements according to the standard PN-EN 303-5:2002. The nominal efficiency of the boiler with a nominal capacity, during the combustion of hard coal is $78 \%$. The boiler was placed in a boiler room built in the mobile laboratory "POLoNEs" (the full name of the laboratory is Przyczyny - Ograniczenie - Likwidacja Niskiej Emisji - causes - reduction - elimination of low stack emissions) (Fig. 1) The boiler system consists of the following elements:

- Automatic feeding 5th class coal boiler (ecodesign requirements fulfill),

- Manual feeding over-fired solid fuel boiler (1st class),

- Air to water heat pump,

- System of heating discharge,

- Measurements and data logging system.

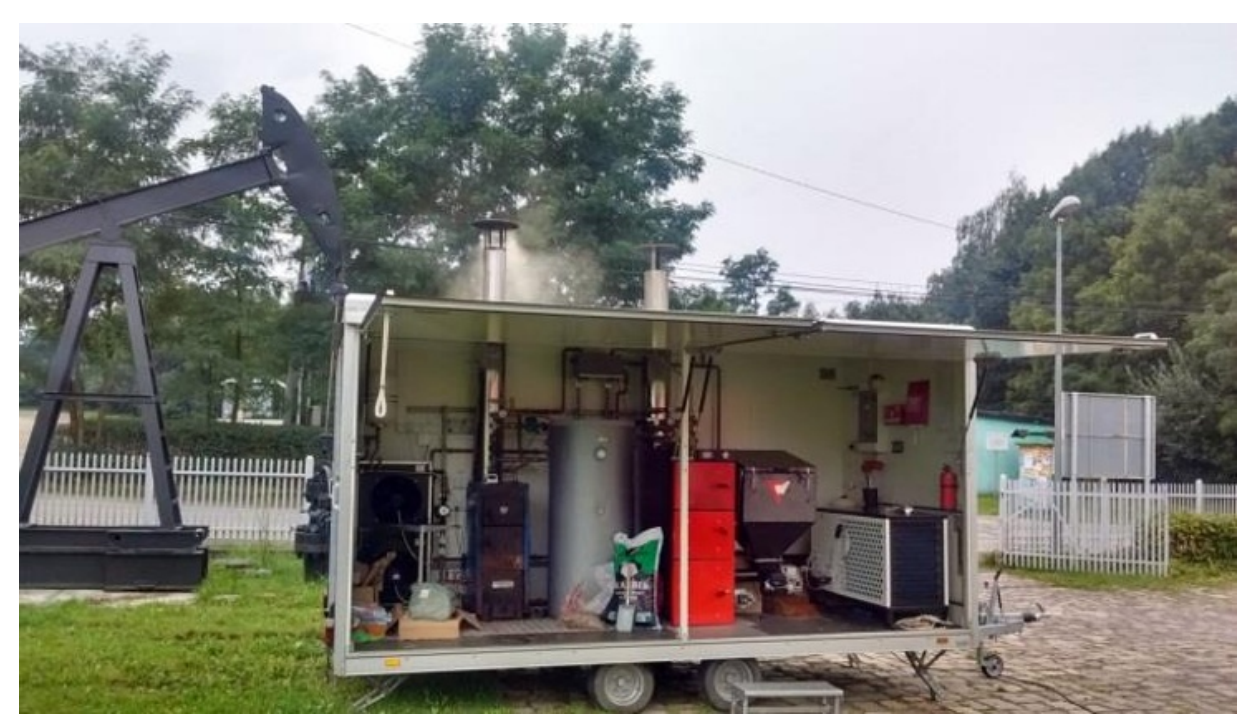

Fig. 1 Mobile laboratory „PoLoNEs”

The system operates in an open loop installation with $75 / 55{ }^{\circ} \mathrm{C}$ parameters. The boilers are equipped with a chimney system, consisting of a heat-insulated telescopic chimney. In 
addition, in order to stabilize the boiler's operating temperature, a water cooler was used whose main purpose was to discharge excess heat from the installation.

In order to determine the efficiency of the boiler, a specified number of selected solid fuels were burned. For testing, wooden logs (seasoned beech), hard coal - nut and hard coal -pie, were chosen as a qualified, packaged fuel. Using a laboratory weight, $5 \mathrm{~kg}$ of each was measured. Thermal energy obtained during the combustion of individual fuels was measured by a heat meter, which was connected to a special controller. As a result, it was possible to read in real time the thermal power capacity of the boiler, inflow and outflow temperatures. After ending the combustion processes, the actual heat energy obtained from the combustion of individual fuels was compared to the amount of chemical energy contained in them, determined on the basis of previous tests. On this basis, the efficiency was determined:

$$
\eta=E_{\mathrm{u}} *\left(Q_{\mathrm{i}} * \mathrm{~m}\right) * 100(\%)
$$

$\eta$ - efficiency $(\%)$

$\mathrm{Eu}$ - obtained energy (heat supply to the system) (kWh)

$\mathrm{Qi}$ - the lower calorific value of fuel converted to $\mathrm{kWh}(\mathrm{kWh} / \mathrm{kg})$

$\mathrm{m}$ - mass of the combusted fuel $(\mathrm{kg})$

\section{Test results}

As can be seen from Table 1, the analyzed wood sample was characterized by a moisture content of $14.20 \%$, which permits the conclusion that the wood had been seasoned for at least two years. It had a low ash content $-0.9 \%$. It had a high share of volatile matter of $71.48 \%$. On the basis of data from the calorimeter, the calorific value of wood which amounted $16.00 \mathrm{MJ} / \mathrm{kg}$ was determined. During combustion $13.61 \mathrm{kWh}$ of thermal energy was obtained. After comparing this value with respect to the total energy contained from the fuel, an efficiency of $60.6 \%$ was obtained. The boiler worked with an average heating capacity of approx. $30 \%$ of the nominal capacity. Heating capacity reached by boiler during test is on figure 2 .

Table 1 Properties of combusted fuels

\begin{tabular}{|l|l|l|l|l|}
\hline Parameter & Unit & $\begin{array}{l}\text { Wooden } \\
\text { logs } \\
\text { (seasoned } \\
\text { beech) }\end{array}$ & $\begin{array}{l}\text { Hard coal } \\
\text { (nut) }\end{array}$ & $\begin{array}{l}\text { Hard coal } \\
\text { (pea) }\end{array}$ \\
\hline Moisture & $\%$ & 14.2 & 8.8 & 8.8 \\
\hline Ash & $\%$ & 0.9 & 5.6 & 5.3 \\
\hline Volatile calorific & $\% \mathrm{MJ} / \mathrm{kg}$ & 71.4 & 36.2 & 35.9 \\
\hline $\begin{array}{l}\text { Lower } \\
\text { value }\end{array}$ & 16.0 & 27.66 & 26.17 \\
\hline
\end{tabular}




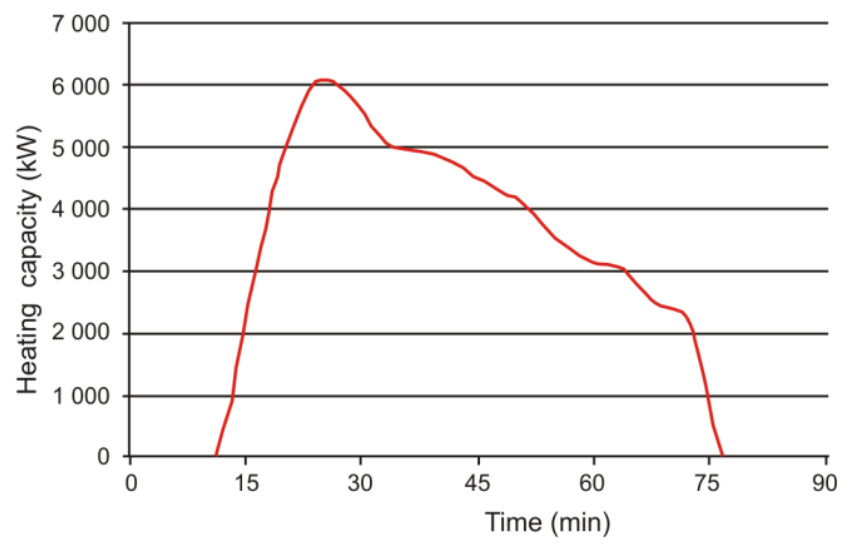

Fig. 2 Heating capacity achieved by the boiler when burning wooden logs

In Table 1 parameters are listed for hard coal -nut. The analyzed sample was characterized by a moisture of $8.82 \%$. Ash content in the fuel was about $5.64 \%$, and the share of volatile parts contained in the fuel was $36.2 \%$. The test sample had a relatively high calorific value, namely $27.66 \mathrm{MJ} / \mathrm{kg}$. During the combustion, $26.135 \mathrm{kWh}$ of heat energy was obtained. After comparing this value in relation to the total energy contained in the fuel, an efficiency equal to $67.7 \%$ was obtained. The boiler worked with an average heating capacity of approx. $45 \%$ of the nominal capacity. Heating capacity reached by boiler during test is on figure 3 .

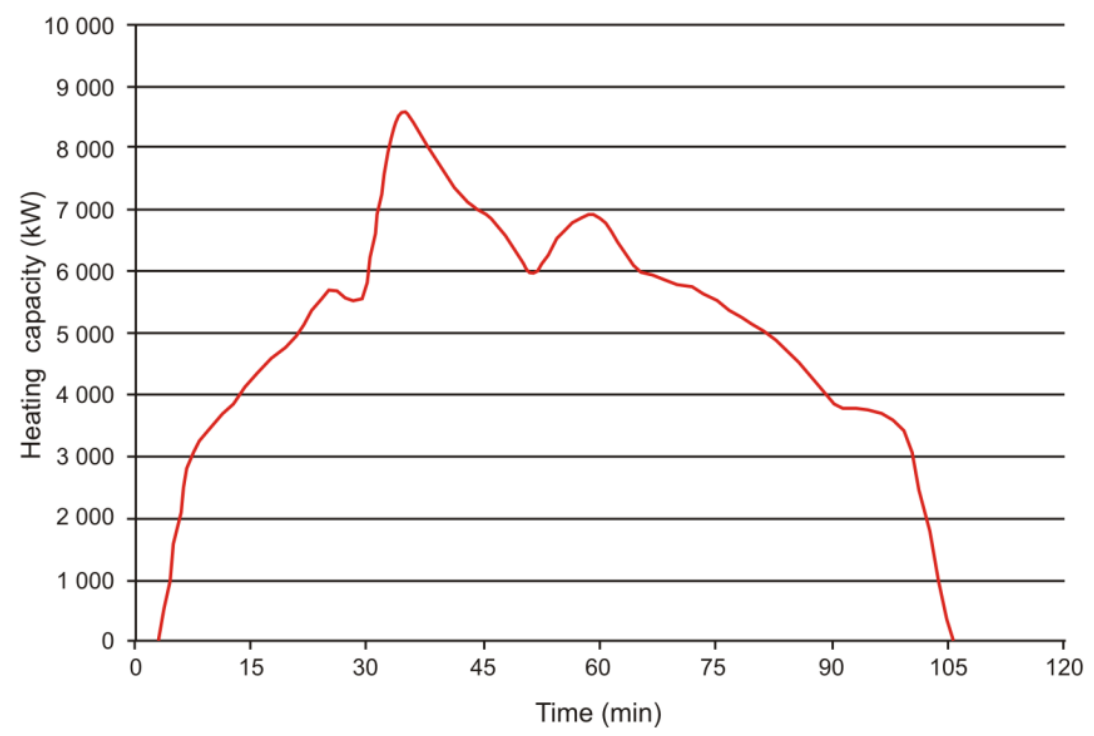

Fig. 3 Heating capacity achieved by the charging boiler when burning hard coal - nut

Pea hard coal was purchased from the same supplier as the previously discussed nut hard coal. It has similar moisture content $-8.80 \%$. The tested sample is characterized by lower ash content, approx. 5.3\% and a slightly lower share of volatile matter of approx. $35.9 \%$. 
On the other hand, the difference in the lower calorific value relative to hard coal-nut is significant, which is lower by $1.5 \mathrm{MJ} / \mathrm{kg}$ and amounts to $26.17 \mathrm{MJ} / \mathrm{kg}$ (Table 1), but the obtained parameters are compatible with the values given by the coal manufacturer. During combustion, $26.6 \mathrm{kWh}$ of heat energy was obtained. After comparing this value to the total energy contained in the fuel, efficiency of $73 \%$ was obtained. The boiler worked with an average heating capacity of approx. 53\% of nominal capacity. Heating capacity reached by boiler during pea coal burning is on figure 4 .

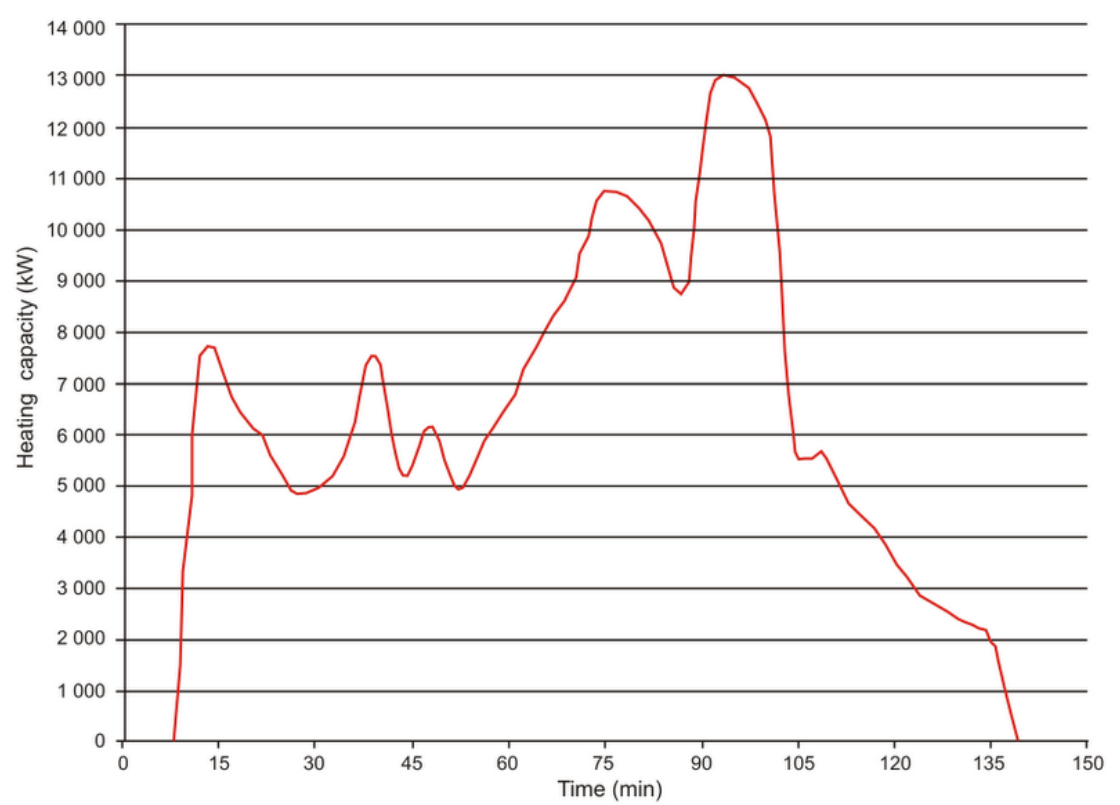

Fig. 4 Heating capacity achieved by the charging boiler when burning pea coal

\section{Summary}

According to the boiler manufacturer, the nominal efficiency which should be achieved during coal combustion in laboratory conditions is $78 \%$. The research shows that in none of the cases considered did the tested solid fuel boiler attain such a value. This fact results mainly from cutting off the supply of primary air to the grate at the moment of reaching the set operating parameters. The result is that the volatile matter contained in the fuel are not completely burned. The main reasons for this are the principles of the construction of the boiler (of the over-fire type) and the dosage of the quantity of fuel, which is not adapted to the temporary heating demand. The lowest efficiency of $60.6 \%$ was obtained during the combustion of dry wood. This is due to the design of the boiler, which is not adapted to the combustion of fuels with a high proportion of volatile matter. In the results, it is clear that the higher the volatile matter content in the fuel, the lower the boiler's efficiency.

Further research would be aimed at determining the boiler's energy performance during the combustion of inferior fuels, e.g. wet wood or fine coal, and a comparison of results and emissions depending on the fuel combusted.

\section{References}


1. M. Kaczmarczyk, M. Kaczmarczyk, G. Pełka, W. Luboń, A. Będkowska, B. Ciapała, D. Malik, E. Podlewska, M. Zboina, Niska emisja efektywność energetyczna $w$ gminach $i$ samorzadach (2017)

2. S. Janiszewski, Rynek Inst., 54-56, 4 (2013)

3. http://www.pie.pl/materialy/_upload/stanowisko_ws_ogr_emisji_2017/Zal_1_Stanowis ko_ws_rek_przez_KRM_PIE_(27012017).pdf

4. GUS (CSO), Energy consumption in households in 2015 (2017)

5. A. Stępniak, A. Tomaszewska, Ubóstwo Energetyczne a efektywność energetyczna, analiza problemu i rekomendacje (2014)

6. http://www.diagnoza.com/pliki/raporty/Diagnoza_raport 2015.pdf

7. $\mathrm{PN}-81 / \mathrm{G}-04516$

8. $\mathrm{PN}-80 / \mathrm{G}-04512$ 